\title{
AUTORYTET BISKUPA RZYMU W NAUCZANIU I PRAKTYCE SW. GRZEGORZA WIELKIEGO
}

Pytając o jakiekolwiek zjawisko czy problem, warto w pierwszej kolejności odwołać się do jego źródeł. Prawda ta dotyczy także zagadnień Kościoła i papiestwa. Poszukując zaś odpowiedzi na pytanie o autorytet biskupa Rzymu, należy skierować spojrzenie na najznamienitszych reprezentantów tej starożytnej stolicy biskupiej. Dlaczego św. Grzegorz Wielki? Wartość jego opinii i przykładu polega już w punkcie wyjścia na tym, iż to właśnie on stanowi, pośród wybitnych biskupów Rzymu, swoisty pomost między antykiem chrześcijańskim a wiekami średnimi ${ }^{1}$. Wychowany wedle reguł klasycznych, wysoki urzędnik w służbie cywilnej, potem kościelnej, a równocześnie mnich i poszukiwacz kontemplacji, staje się $\mathrm{w}$ końcu jednym $\mathrm{z}$ promotorów ewangelizacji Europy, równocześnie niestrudzenie pracującym nad pozycją biskupa Rzymu, tak wobec władzy świeckiej, jak i duchowieństwa, tak wobec wschodniej, jak i zachodniej części nowego świata, tworzącego się właśnie na gruzach świetnego ongiś Imperium Romanum. Jeśli nadto wspomnimy jeszcze, iż obchodzimy 1400 rocznicę jego śmierci, odwołanie się do tego akurat autora nie wymaga dalszego uzasadniania.

Jeśli chodzi o status quaestionis, to trzeba podkreślić, iż na temat postaci, działalności i nauki Grzegorza napisano już wyjątkowo wiele publikacji, a wśród nich nie brakuje także i takich pozycji, które traktują wprost o autorytecie. Można tu m.in. wspomnieć artykuł P. Meyvaerta z 1966 r. pt. zatytułowany Grzegorz Wielki $i$ temat autorytetu ${ }^{2}$; a także pokaźną wzmiankę w datowanym na 1969 r. dziele K.F. Morrisona na temat tradycji i autorytetu w Kościele Zachodnim ${ }^{3}$ oraz dysertację przedstawioną w 1971 r., na Uniwer-

1 Por. J.L. Maier, Le dossier du donatisme, II, Berlin 1989, 347: „A l'heure actuelle le pape saint Grégoire, premier du nom, est encore un de plus illustres de tous les successeurs de Pierre sur le Siège apostolique et son pontificat, qui dura du 3 septembre 590 au 12 mars 604 , doit être rangé parmi les plus importants de toute l'histoire de l'Église".

${ }^{2}$ Por. P. Meyvaert, Gregory the Great and the theme of authority, "Spode House Reviev" 3 (1966) 3-12.

3 Por. K.F. Morrison, Tradition and authority in the Western Church (300-1140), Princetown $1969,124-140$. 
sytecie Laterańskim przez J. Bosmana ${ }^{4}$. Można tu też wspomnieć stosunkowo nowe pozycje Leysera ${ }^{5}$ i Nicholsona ${ }^{6}$. To tylko niektóre exempla, specjalnie wyliczone ze względu na bezpośrednie referencje do naszego tematu. Oprócz nich znajdujemy mnóstwo innych, rozproszonych po różnych publikacjach, traktujących już to o relacjach Grzegorza $z$ władcami ówczesnego świata, już to o relacjach $z$ biskupami tak Wschodu jak i Zachodu, o aspektach religijnych, prawnych i o życiu codziennym wraz z całym jego bagażem: we wszystkim tym możemy odnaleźć wiele refleksji na interesujący nas temat. Można to jeszcze uzupełnić we własnym zakresie, chociażby przez kontakt $\mathrm{z}$ doskonałym instrumentem naukowym, jakim jest opracowana przez R. Goddinga Bibliografia św. Grzegorza Wielkiego, obejmująca okres 1890-19897.

Idąc szlakiem wyznaczonym przez podjęty temat spróbujemy w toku naszego wywodu przyjrzeć się poglądom wielkiego Papieża na pochodzenie autorytetu oraz rolę i pozycję biskupa Rzymu, kolejno wobec Kościoła na Wschodzie i na Zachodzie; następnie odwołamy się do relacji z władcami i urzędnikami, opierając się głównie na jego obfitej korespondencji. Niejednokrotnie płaszczyzny teorii i praktyki wzajemnie się przenikają, co utrudnia nieco znalezienie właściwego punktu widzenia, lecz nie stanowi bariery nie do przebycia.

\section{I. ŹRÓDłA AUTORY'TETU}

Odwołując się do humorystycznego, choć napisanego w trudnych dlań okolicznościach zdania naszego autora, możemy już na wstępie stwierdzić, że biskup Rzymu powinien być „lwem”, co można wnioskować z listów do Teoktysty $^{8}$, siostry cesarza Maurycjusza i do Narzesa ${ }^{9}$, w których żali się na wyrwanie go $\mathrm{z}$ klasztornego zacisza. Posłannictwo, do którego został powołany, prze-

\footnotetext{
${ }^{4}$ Por. J. Bosman, Authority in the discourses of St. Gregory the Great, Roma 1971.

5 Por. C. Leyser, Authority and asceticism from Augustine to Gregory the Great, Oxford 2000.

${ }^{6}$ Por. G. Nicholson, The Understanding of Papal Supremacy as revealed in the Letters of Pope Gregory the Great. Artykuł dostępny jest w wersji sieciowej pod nastepującym adresem: www.uq.edu.au/access_history/one-two/gregory.pdf. (The University of Queensland On-Line History Journal., Access: History Vol. 1, No. 2., Academic Essays, 49, s. 49-65). Autor niniejszego opracowania nie dotarl do wydania drukowanego.

7 Por. R. Godding, Bibliografia di Gregorio Magno (1890-1989), Roma 1990.

${ }^{8}$ Por. Epistula I 5, CCL 140, 7, thum. J. Czuj: Św. Grzegorz, Listy, I-IV, Warszawa 1954-1955, I 7: „Oto najjaśniejszy pan, cesarz, kazał małpie, aby stała się lwem (domnus imperator fieri simiam leonem iussit). I oczywiście na jego rozkaz może się lwem nazywać, stać się natomiast lwem ni może".

${ }^{9}$ Epistula I 6, CCL 140, 8, Czuj I 9: „Zaiste, Bracie Najdroższy, malpę nazywam lwem; widzę, że postępujecie podobnie jak ci, którzy nieraz nazywaja parszywe pieski lampartami lub tygrysami".
} 
rażało go. I tu, na samym początku swego pontyfikatu, porównując się bynajmniej nie do lwa, lecz do małpy, daje nam znak, iż należy rozgraniczyć autorytet urzędu od autorytetu osoby. Dla Grzegorza autorytet, nawet biskupa Rzymu, nie jest szczytem, do którego dąży. Szczytem jest kontemplacja Boga.

„Ponad wysokości bowiem wznosi się ten, kto z pogardą w sercu odrzuca nawet i to, co wydaje się wzniosle i chwalebne na tym świecie"10.

Podobny ton pobrzmiewa w dalszych listach, szczególnie pisanych do dawnych znajomych i przyjaciół. A jednak z urzędem, który podejmuje osoba, łączy się autorytet.

Jest to przede wszystkim autorytet pasterski. Pierwszym zaś pasterzem jest Chrystus, ale zaraz po Nim tytuł pasterza i - siłą rzeczy - związany z nim autorytet, przysługuje św. Piotrowi, jak to napisze Grzegorz do wspomnianej Teoktysty dziesięć lat później:

„Przecież Piotr otrzymał władzę w Królestwie Niebieskim, aby cokolwiek zwiąże lub rozwiąże na ziemi, było związane lub rozwiązane w niebie"11.

Nie sposób nie zauważyć, iż swą wizję opiera wyraźnie na słowach Ewangelii (Mt 16, 19). Nieco dalej nazwie Piotra, zresztą nie tylko w tym miejscu, „Pasterzem Kościoła” i „Księciem Apostołów”. Nazwie go też wprost „pierwszym pasterzem Kościoła"13. Dzierży on z woli Bożej pierwszeństwo w Kościele świętym ${ }^{14}$. O autorytecie Piotra mówi też wiele kult na ówczesne czasy nader pokaźnie rozwinięty, a przejawiający się choćby w czci słynnych kluczy św. Piotra ${ }^{15}$, tytułach kościołów, klasztorów. Nie ma tu potrzeby rozwijania tego zagadnienia, wiadomo bowiem, iż Tradycja Kościoła przyznawała od początku szczególne miejsce temu apostołowi. Grzegorz był tylko wiernym kontynuatorem tej tradycji już wówczas wielowiekowej ${ }^{16}$.

${ }^{10}$ Epistula I 5, CCL 140, 5, Czuj I 6.

11 Epistula XI 27, CCL 140A, 907, Czuj IV 76.

12 Tamże, CCL 140A, 908: „pastor Ecclesiae apostolorum princeps”; Czuj IV 76. Określenia tego używa św. Grzegorz kilkadziesiąt razy. Nie ma potrzeby przytaczać tu wszystkich referencji. Pełną ich listę możemy znaleźć w: V. Recchia (red.), Opere di Gregorio Magno, Lettere, V/4, Roma 1999, 481.

${ }_{13}$ Regula pastoralis II 11, SCh 381, 256, tłum. E. Szwarcenberg-Czerny, ŹM 30, 115: „Pierwszy pasterz Kościoła dobrze naucza innych pasterzy mówiąc (1P 3, 15)".

${ }^{14}$ Por. Epistula I 24.

15 Klucze św. Piotra były to swego rodzaju relikwiarze, w formie kluczy, zawierające male fragmenty okowów św. Piotra. Grzegorz zaświadcza o ich cudownej mocy, zob. Epistulae I 22, 25, 30; III 33, 47; IV 27, 30; V 42, 46; VI 6, 58, etc.; por. M. Harrsen, Pope Gregory the Great as Guardian of the Apostolic Relics, „Nederlands Kunsthistorisch Jaarboek” 5 (1954) 305-307.

${ }^{16}$ Por. V. Saxer, Pietro apostolo, DPAC II 2784-2789. 


\section{AUTORYTET BISKUPA RZYMU WOBEC PATRIARCHATÓW WSCHODNICH}

Samorzutnie nasuwa się tu pytanie, czy dla naszego autora z pierwszeństwa Piotra wynika pierwszeństwo biskupa Rzymu? Odpowiedź nie jest prosta. Grzegorz jest świadom wielkości swego świętego poprzednika i świadom znaczenia Piotrowej stolicy ${ }^{17}$. Jak sam podkreśla w liście synodalnym do patriarchów $^{18}$, decyzje soborów szanuje jak Ewangelie ${ }^{19}$, a przecież właśnie w kanonach soborowych znajdujemy oficjalne potwierdzenie pierwszeństwa stolicy rzymskiejj $^{20}$. A jednak świadom jest także, iż stolicami Piotrowymi są również Antiochia i Aleksandria. Świadomość tego faktu potwierdza nasz święty pisząc do Anastazjusza, biskupa Antiochii ${ }^{21}$ i do Eulogiusza z Aleksandrii ${ }^{22}$. W jednym $z$ listów skierowanych w lipcu $597 \mathrm{r}$. do tegoż Eulogiusza, znajdujemy na ten temat interesujący tekst, który warto, mimo długości, przytoczyć:

"Wiele przemiłych rzeczy powiedziała mi w swym liście Wasza Swiątobliwość o stolicy św. Piotra, Księcia apostołów i o tym, że on aż dotąd zasiada na niej w swych następcach. A ja właśnie uważam się za niegodnego nie tylko w dostojeństwie zasiadających, lecz nawet w liczbie stojących. Ale wszystko, co tam było powiedziane, chętnie przyjąłem, bo mówił do mnie o Stolicy Piotra ten, który na Stolicy Piotra zasiada. A chociaż szczególna godność wcale mnie nie bawi, to jednak bardzo się ucieszyłem, że wy, najświątobliwsi, sobie oddajecie to, co mnie przyznajecie. Któż nie wie, że Kościól święty umocniony jest na stałości Księcia apostołów, który moc umysłu wyraża w imieniu, gdyż Piotr od opoki bierze imię. Jemu to głosem Prawdy powiedziano: «Tobie dam klucze królestwa niebieskiego» (Mt 16, 19). Jemu także powiedziano: «Ty zaś, nawróciwszy się w przyszlości, utwierdzaj braci twoich» ( $(k \mathrm{k} 22,32)$ i jeszcze: «Szymonie, synu Jana, miłujesz mię? Paś owce moje» (J 21, 17). Toteż choć wielu jest apostołów, jednak dla samego pierwszeŕstwa jedna Stolica Księcia apostołów wzrosła w powagę,

${ }^{17}$ Por. E. Langiardi, S. Pietro nelle omelie di san Gregorio Magno, Diss. Univ. S. Cuore, Milano 1971; C. Poulet, Histoire du Christianisme, t. 1: Antiquité, Paris 1932, 821-828 (La primauté romaine sous S. Grégoire le Grand).

${ }^{18}$ Tzn. Jana z Konstantynopola, Eulogiusza z Aleksandrii, Grzegorza z Antiochii i Jana z Jerozolimy oraz Anastazjusza, złożonego z urzędu patriarchy Antiochii, później przywróconego do lask.

${ }^{19}$ Por. Epistula I 24, CCL 140, 32, Czuj IV 45: „wyznaję, iż przyjmuję i czczę tak cztery księgi swiętej Ewangelii, jak i cztery sobory [...] na nich bowiem, jakby na czworobocznym kamieniu wznosi się dudowa wiary świętej".

${ }^{20}$ Kanon III Soboru Konstantynopolitańskiego I (381), abstrahując od związanych z nim reperkusji, przyznaje miejsce Konstantynopolowi po Rzymie, który jest, oczywiście, pierwszy, por. Concilium Constantinopolitanum I, can. 3, tłum. T. Wnętrzak, w: Dokumenty Soborów Po. wszechnych. Tekst grecki, tacinski, polski, t. 1: (325-787), red. A. Baron - H. Pietras, ZMT 24, Kraków 2001, 73: „Biskup Konstantynopola powinien mieć honorowe pierwszeństwo po biskupie Rzymu".

${ }^{21}$ Por. Epistula V 42, CCL 140, 325-327, Czuj II 117-119.

${ }^{22}$ Por. Epistulae VI 61 i VII 57, CCL 140, 434-435 i 500-502, Czuj II 232-234 i 300-302. 
a w trzech miejscach jest wlasnościa jednego. On bowiem wywyższył Stolicę, w której [w Rzymie] także raczył spocząć i zakończyć doczesne życie; on ozdobił Stolicę [Aleksandrię], na którą posłał ucznia ewangelistę; on utrwalił Stolicę [Antiochię], na której przez siedem lat zasiadal, zanim stamtąd odszedr ${ }^{23}$.

Mowa, oczywiście, po kolei o Rzymie, gdzie św. Piotr spędził ostatnią część swego życia, Aleksandrii ${ }^{24}$, założonej przez św. Marka, a w końcu o Antiochii ${ }^{25}$. Wymienienie Rzymu na pierwszym miejscu mogłoby znaczyć bardzo wiele, gdyby Grzegorz nie dodał zaraz:

„Skoro więc jednego wladcy jedna jest stolica, na której z upoważnienia Bożego obecnie zasiada trzech biskupów, to cokolwiek słyszę o was dobrego, przypisuję sobie, jeżeli coś dobrego wy o mnie mniemacie, przypiszcie swoim zasługom, ponieważ jedno jestesmy w Tym, który mówi: «Aby wszyscy byli jedno, jak Ty, Ojcze, we mnie a ja w Tobie, aby i oni byli jedno w nas"” $(\mathrm{J} 17,21)^{26}$.

Wobec powyższych słów nie dziwi chyba nikogo, iż idei prymatu, przynajmniej w rozumieniu takim, jak w wiekach późniejszych, czy choćby jak jest dziś rozumiana, u naszego autora doszukiwać się jest trochę niezręcznie. Co więcej, teksty Grzegorza mogą służyć uzasadnianiu stanowiska odmiennego od katolickiego, co pokazuje nam zdanie prawosławnego autora Gregorio Cognettiego, który w tytule artykułu na powyższy temat zwie św. Grzegorza dosłownie: „papieżem, który potępił prymat”27. Oczywiście, jest to opinia przesadzona; raczej można rzec, że pojmował on ideę przewodnictwa w sposób „swoisty”. J. Czuj, thumacz listów i znawca biografii biskupa Rzymu powie tu, iż „u patriarchów Wschodu cieszył się papież poważaniem, ale raczej jako równy im godnością patriarcha Zachodu, niż jako głowa całego Kościoła"28. Nie wydaje się też, by Grzegorz ze swej strony próbował narzucać się innym z jakimiś władczymi aspiracjami, chyba, że chodzi o sprawy wiary.

Jeśli spróbujemy postawić tu pytanie o naturę autorytetu biskupa rzymskiego, to przynajmniej w relacji do patriarchów Aleksandrii i Antiochii, leży on nie tyle we władzy zwierzchniej, co w pierwszeństwie widzianym z perspektywy miłości i braterstwa. Sprawa autorytetu wobec chrześcijańskiego Wschodu komplikuje się, gdy zapytamy o relację wobec stolicy patriarszej, która nie

${ }^{23}$ Epistula VII 37, CCL 140, 500-501, Czuj II 300-301.

24 Za pontyfikatu Grzegorza na stolicy antiocheńskiej zasiadali kolejno: Grzegorz I Synaita (570-593), Anastazy I Synaita (593-598; powtórnie, wcześniej usunięty) i Anastazy II Synaita (598-609).

${ }^{25} \mathrm{~W}$ Aleksandrii tron patriarszy zajmowal w tym czasie Eulogiusz (580-607).

26 Epistula VII 37, CCL 140, 501, Czuj II 301.

27 Por. G. Cognetti, The Pope who condemned Primacy, „The Down”, czerwiec 1993. Korzystałem z wersji sieciowej (http:/www.roca.org/oa/126-127/126e.htm) z powodu trudności w dotarciu do drukowanej. Na ten temat dostępny jest też tekst tego samego autora w języku wloskim, na stronje internetowej: http://www.ortodossia.info/Teologia14.htm.

28 J. Czuj, Papiez Grzegorz Wielki, Warszawa 1948, 21. 
cieszyła się pochodzeniem od św. Piotra, mianowicie o „nowy Rzym”29, czyli stolicę cesarstwa. Tu równowaga została zachwiana przez hierarchów używających tytułu „patriarchy ekumenicznego" ${ }^{30}$. I chociaż biskup Rzymu wymienia np. Jana IV Postnika, zgodnie ze wspomnianym już III kanonem Soboru Konstantynopolitańskiego, na pierwszym miejscu w swym liście synodalnym przesłanym do wschodnich stolic patriarszych po wyborze ${ }^{31}$, a nawet wydaje się pozostawać z nim w dobrej relacji, sięgającej jeszcze czasów pobytu w Konstantynopolu, to przeciw jego krokom energicznie protestuje. Wspomnieć tu możemy chociażby sprawę Jana z Chalcedonu, podejrzanego o herezję, oraz mnichów izauryjskich na czele z kapłanem Atanazym, obitym kijami w kościele konstantynopolitańskim. Grzegorz śmiało ingeruje tu w sprawy wschodniego patriarchatu, powołując się zresztą na kanony i upominając swego brata w biskupstwie ${ }^{32}$. Uwidacznia się tu ze strony Grzegorza świadomość autorytetu, który posiada na mocy zasiadania na stolicy rzymskiej. Gorzej z akceptacja tegoż autorytetu ze strony Jana Postnika, aczkolwiek w końcu przynajmniej sprawa pokrzywdzonych duchownych znajduje pozytywny finat ${ }^{33}$.

Pojawia się natomiast sygnalizowany powyżej problem, mianowicie tytuł „patriarchy ekumenicznego", którego nagminnie używają najpierw Jan, a potem jego następca, Cyriak. Dla Grzegorza tytuł ten jawi się jako wyraz pychy i zgorszenia ${ }^{34}$. Przeciw takim krokom protestuje on energicznie, aczkolwiek bezskutecznie. Sprawa ta, mimo odwołań do cesarza i jego małżonki oraz do

29 Jest to określenie Soboru Konstantynopolitańskiego I (kan. 3). Tu patriarchami za czasów Grzegorza byli kolejno: Jan IV Postnik (582-595) i Kyriakos [Cyriak] (596-606), por. F. Dvornik, Byzance et la primauté romaine, Paris 1964, 69-72.

${ }^{30}$ Por. A. Tulier, Grégoire le Grand et le titre de patriarche oecuménique, w: Grégoire le Grand (Colloques internationaux du CNRS), Paris 1986, 69-82.

31 Por. Epistula I 24, CCL 140, 22, Czuj I 32: „Grzegorz do Jana Konstantynopolitańskiego, Eulogiusza Aleksandryjskiego, Grzegorza Antiocheńskiego [...]".

32 Por. Epistulae III 52 i 63, CCL 140, 197-199 i 213-214, Czuj I 229-231 i 246-247.

33 Duchowni owi, oskarżeni zresztą o herezję, po odwołaniu się do Grzegorza, zostali uwolnieni. Jan, oczyszczony z podejrzenia o dzielenie poglądów marcjonitów, przez synod rzymski (zob. Epistulae VI 14 i 15), zaś nieco później Atanazy, po komplikacjach związanych z kolejnymi podejrzeniami o pelagianizm (zob. Epistula VII 4). Szerszych informacji na temat całej sprawy możemy zasięgnąé w: Czuj, Papież Grzegorz Wielki, s. 163-166.

34 Jasno i klarownie pogląd na tę sprawę wykłada Grzegorz choćby w liście do Jana Postnika, z czerwca 595 r. (Epistula V 44, CCL 140, 330, Czuj II 121), gdzie m.in. czytamy: „[...] proszę, błagam i żądam z taką słodyczą, z jaką tylko mogę, abyście, Czcigodny Bracie, sprzeciwiali się wszystkim pochlebcom i tym, którzy ofiarowują wam urojony tytul, i byście nie zgadzali się, by was nazywano głupim i pysznym wyrazem". Problem nie był niczym nowym, tytuł ten bowiem pojawia się już wcześniej. Za pontyfikatu Grzegorza jedynie się nasilit. Dla otrzymania całościowego oglądu warto sięgnąć też do innych listów, jak: Epistulae V 37, 39, 41, 45; VII 24, 28, 30; VIII 29; IX 157; por. R. Markus, Grzegorz Wielki, Warszawa 2003, 111-117; M. Sotomayor, El rechazo radical del título de „papa universal" por parte de Gregorio Magno, w: Dalla Chiesa antica alla Chiesa moderna, Roma 1983, 57-77; Tulier, Grégoire le Grand, s. 69-82; S. Vailhé, S. Grégoire le Grand et le titre de Patriarche oecuménique, „Echos d'Orient” 11 (1908) 161-171. 
innych patriarchów, osiągnąwszy swe apogeum w piątym roku Grzegorzowego pontyfikatu, będzie ciągnęła się już do śmierci rzymskiego biskupa, który dla równowagi i przeciwstawienia się uzurpacji wschodniego brata, przyjął tytuł „servus servorum Dei”,35, podkreślając, iż sam nie chce używać tytułu „powszechny" 36 . Jak wykazuje chociażby J. Czuj, tytuł „powszechny” bywał używany wcześniej zarówno w stosunku do papieży, jak i patriarchów ${ }^{37}$. Różnica polega na tym, iż biskupi Rzymu nigdy nie rościli sobie pretensji do jego używania, zaś Jan wyraźnie sam go sobie przywłaszczył. Problem ten doczekał się obfitej literatury, czuję się zatem zwolniony z konieczności wyjaśniania wszystkich jego detali ${ }^{38}$. Warto tylko zauważyć, iż autorytet biskupa rzymskiego w tym wypadku okazał się zdecydowanie ograniczony.

Jeśli chodzi o inne Kościoły wschodnie, to zarówno ze strony biskupa Jerozolimy, jak i innych, dostrzegamy przejawy szacunku wobec biskupa Rzymu, ze strony zaś Grzegorza troskę o sprawy Kościoła, jak to zauważamy choćby w przypadku konfliktu pomiędzy klasztorem w Neas, reprezentowanym przez kapłana Anastazjusza, a biskupem jerozolimskim ${ }^{39}$, w którą to sprawę Grzegorz autorytatywnie ingeruje, podobnie, jak i w sprawę zbiegłego z Konstantynopola akolity Piotra, którego poleca zatrzymać i odesłać do Rzymu. Prośbę tę motywuje w wymowny sposób:

„Ponieważ ufamy; czcigodny bracie, że miłujecie postanowienie kanoniczne i sprężystą karność kościelną" ${ }^{40}$.

Znawca prawa doskonale zdaje sobie sprawę z pierwszeństwa, które mu przysługuje w cesarstwie, nawet mimo zakusów tytularnych brata $\mathrm{z}$ cesarskiego miasta ${ }^{41}$. Jest ono zresztą potwierdzane przez korespondujących $z$ nim przedstawicieli Wschodu i odwoływanie się do jego właśnie autorytetu ${ }^{42}$.

${ }^{35}$ Tytul ten jest rozwiniętą formą wcześniej używanego w formulach kancelaryjnych tytułu "servus Dei”, por. E. Peretto, Servus Dei, DPAC II 3165-3166; I. Schuster, ll titolo di "servus Dei” nell'epistolario di s. Gregorio Magno, „La Scuola cattolica” 73 (1945) 137-138; E.F. Sutcliffe, Servus sevorum Dei, „Clergy Reviev” 6 (1933) 378-386.

36 Por. Epistula V 41, CCL 140, 321, Czuj II 113: „Jak bowiem Czcigodna Świątobliwość wie, tytuł „powszechny” ofiarowany został przez święty synod chalcedoński arcykapłanowi Stolicy Apostolskiej, której ja z woli Bożej służę"; Epistula V 41, CCL 140, 310, Czuj II 102: „Dlaczego więc my tego pysznego tytułu - choć nam go ofiarowano - nie pragniemy, a drugi śmie przywłaszczać go sobie, choć mu go nie ofiarowują?".

${ }^{37}$ Por. Czuj, Papiez Grzegorz Wielki, s. 171; S. Vailhé, Le titre de patriarche oecuménique avant saint Grégoire le Grand, „Echos d'Orient” 11 (1908) 65-69.

38 Por. Godding, Bibliografia di Gregorio Magno, s. 60-61.

39 Biskupem Jerozolimy był wówczas Amos, a od $601 \mathrm{r}$. Izacjusz. W powyższej sprawie zob. Epistula VII 29.

40 Epistula VIII 6, CCL 140A, 523, Czuj III 16.

${ }^{41}$ Por. Markus, Grzegorz Wielki, s. 104.

42 Wspomnieć tu wystarczy choćby zapytania biskupa Kwiryka z Hibernii o nawracających się $\mathrm{z}$ herezji nestoriańskiej. Wedle danych zawartych w piśmie naszego Autora, chodzi o krainę na 


\section{ITALIA, AFRYKA I KOSCIOŁY ZACHODU}

Jak podkreśla J. Czuj, „biskup rzymski od najdawniejszych czasów miał tytuł patriarchy"43. Przez to samo sprawował także władzę nad poszczególnymi metropoliami, wchodzącymi w skład zachodniego patriarchatu. Celowo rozdzielamy tu Italię i Kościoły zachodnie, bowiem, jak wiadomo, Italia znajdowała się pod wpływami cesarstwa, od którego w jakiś sposób zależała. Nie podlega dyskusji kwestia autorytetu biskupa Rzymu w samym Rzymie, w owych czasach podupadłym, liczącym ok. 50 tys. mieszkańców. Były jednak wówczas i inne, wcześniej już aspirujące do szczególnej roli miasta, jak np. Rawenna, honorowana przez władców ${ }^{44}$. W czasach Grzegorza to tu właśnie, nie w Rzymie, rezydowal cesarski egzarcha, choć w 592 r. między jego siedzibą a Rzymem stacjonowali już Longobardowie. W pierwszym okresie pontyfikatu Grzegorza biskupem Rawenny był Jan II (III ${ }^{45}$, stary znajomy naszego bohatera, pozostający $\mathrm{z}$ nim $\mathrm{w}$ miarę przyjaznych relacjach, zmąconych, niestety, kwestią używania przez Jana paliusza poza Mszą św. oraz kapy przez podległych mu niższych duchownych. Konflikt ten będzie się ciągnął do śmierci Jana († 594), który zanim wyzionął ducha, zdążył pozwolić sobie na samowolne używanie wspomnianej szaty i na kpiny $z$ decyzji papieskich. Nie był to niby wielki problem, bo nie dotyczył wiary, ale podważał w jakiś sposób autorytet papieski. Marynian ${ }^{46}$, kolejny biskup Rawenny, także przysparzał wiele kłopotów, bo choć znany jest naszemu Świętemu z jego wspólnoty monastycznej, to daje się niekiedy kierować podszeptom ludzi niechętnych Rzymowi. Mimo tych ciemnych stron relacje $\mathrm{z}$ obydwoma hierarchami miał Grzegorz względnie dobre, dedykując im zresztą swoje dzieła - pierwszemu Regułe pasterska, drugiemu zaś księgę Homilii na Ezechiela.

Nie było natomiast żadnych problemów $\mathrm{z}$ akceptacją autorytetu biskupa Rzymu na południu od „Wiecznego Miasta”, przeżywającego teraz akurat swój trudny okres. Grzegorz prowadził obfitą korespondencję, sprawował nadzór za pomocą swoich przedstawicieli i rektorów, jak np. subdiakon Antemiusz z Kampanii ${ }^{47}$, defensorów, notariuszy, biskupów, zajmuje się sprawami dyscy-

południe od Kaukazu (Hiberia Pontica), w odróżnieniu od Hiberii (dziś Hiszpania) i Hibernii (dziś Irlandia). List hierarchy wschodniego jakoby zaginąl, lecz mamy odpowiedź Grzegorza, por. Epistula XI 52, CCL 140A, 952-956, Czuj IV 114-117.

${ }^{43}$ Por. Czuj, Papież Grzegorz Wielki, s. 64. Na patriarchat zachodni składały się metropolie Rawenny, Mediolanu i Akwilei, południowa Italia oraz Sycylia, Sardynia, Korsyka i Malta, a także Galia, Hiszpania, Afryka, Dalmacja, Macedonia, Tessalia, Prima Iustiniana, Achaja i Epir.

44 Por. R. Markus, Ravenna and Rome (554-604), „Byzantion” 51 (1981) 566-578.

45 Por. Markus, Grzegorz Wielki, s. 176.

46 Por. tamże, s. 177-178.

47 Obfita korespondencja z Antemiuszem obrazuje dobrze przyjęty przez Grzegorza system gospodarowania. Dowiadujemy się z niej o takich obowiązkach, jak wypłacanie zasiłków mniszkom, opieka nad ubogimi, dbałość o dyscyplinę monastyczną, troska zarówno o sprawy duchowe, 
pliny zarówno diecezjalnej, jak i klasztornej. Nadmienić też warto, iż południowa Italia wraz z Sycylią, stanowiła swoisty spichlerz dla Rzymu; tu bowiem mieściły się papieskie majątki, czyli tzw. ,patrimonium Petri”48.

Oczywiście nie obywało się bez konfliktów. Te jednak generalnie nie podważały autorytetu rzymskiego biskupa, poza jednym: w Italii za czasów Grzegorza istniał konflikt zwany schizmą istryjską, która swoje źródło znajdowała w słynnej, od dawna już ciągnącej się sprawie tzw. „trzech rozdziałów" "49. Schizmatycy robili wszystko, by tylko nie mieć do czynienia $z$ biskupem Rzymu, łącznie z odwoływaniem się do cesarza, który zakazał Grzegorzowi nękać krnąbrnych hierarchów. Teoretyczne „zwycięstwo” Grzegorza pod koniec jego życia nie uchroniło jednak północnej Italii od nowego porządku w sferze wpływów eklezjalnych, bo choć biskup Rzymu cieszył się z jedności wiary, to stracił wpływy w obszarze zdominowanym przez schizmatyków a zajętym przez Longobardów. Owocem tego było np. zachowanie tytulu „patriarchy” przez biskupa Akwilei ${ }^{50}$.

Biskup Rzymu cieszył się niewątpliwie poważaniem w metropolii Salony ${ }^{51}$, czyli na terenach Ilirii Zachodniej ${ }^{52}$, o czym świadczy np. odniesienie się doń w sprawie hulaszczego biskupa Natalisa ${ }^{53}$. Poważanie to jednak nie jest bezdyskusyjnym poddaniem się autorytetowi rzymskiego hierarchy, o czym świadczy problem $z$ jeszcze gorszym następcą wspomnianego hulaki, nieprawnie wybranym Maksymem, zresztą jedynym duchownym, którego Grzegorz wykluczyl $\mathrm{z}$ grona kandydatów do biskupstwa ${ }^{54}$, a popieranym przez władze

jak i materialne, por. Epistulae I 23, 37, 40, 48, 53, 57, 63, 66; IV 31; VI 23, 32, 37; VII 20; IX 36, 62, 69, 85, 88, 89, 95, 106, 109, 122, 137, 143, 145, 164, 191, 193, 194; X 7; XI 53; XIII 27, 29.

48 Por. G. Arnaldi, Gregorio Magno, $i$,patrimoni di S. Pietro" e le autorità imperiali in Italia e in Sicilia, w: Miscellanea in onore di Reggero Moscati, Napoli 1985, 39-46; tenże, L'approvvigionamento di Roma e l'amministrazione dei "Patrimoni di S. Pietro" al tempo di Gregorio Magno, „Studi Romani” 34 (1986) 25-39; P. Brown, Narodziny zachodniego chrześcijanistwa, tlum. J.W. Popowski, Warszawa 2000, 160.

${ }^{49}$ Chodzi o osobę i dziela jednego z twórców nestorianizmu, Teodora z Mopsuestii, pisma Teodoreta z Cyru przeciw św. Cyrylowi i Soborowi Efeskiemu oraz list Ibasa z Edessy do Persa Marisa w obronie Teodora, oskarżający Cyryla o apolinaryzm. Teodoret oraz Ibas powrócili do jedności pod wpływem soboru w Chalcedonie, po wyklęciu Nestoriusza. W związku z powyższym odłożono ad acta sprawę ich pism. Potępił je natomiast Justynian w swoim edykcie z 544 r., czego nie zaakceptował Kościól zachodni. I choć papież Wigiliusz (537-555) naciskany przez cesarza, zaakceptowal w końcu potępienie trzech rozdziałów, zaowocowało to rozłamem w łonie Kościola. Sobór Konstantynopolitański II (553) załagodził sytuację, aczkolwiek poza jednością pozostali biskupi istryjscy, por. Markus, Grzegorz Wielki, s. 150-170; M. Simonetti, Tre capitoli (questione dei), DPAC II 3507-3508.

${ }^{50}$ Por. Markus, Grzegorz Wielki, s. 160.

51 Chodzi o Salonę w Dalmacji.

52 Por. I. Coman, Grégoire et les Églises illyryco-thraco-daco-romaines, w: Grégoire le Grand (Colloques internationaux du CNRS), s. 95-105.

53 Por. Epistulae I 10, 19; II 17-20, 38.

54 Por. Epistula IV 16, CCL 140, 235, Czuj II 24: „Wyjątek stanowi jedynie osoba Maksyma, o którym wiele złego nam doniesiono. A jeśli on nie zaprzestanie ubiegać się o wyższą godność, nic 
i duchowieństwo. Święty biskup Rzymu będzie się borykał z tą sprawą (właściwie rozłamem) przez kilka lat, przy czym zakończy się ona akceptacją uzurpatora, a nawet nadaniem mu paliusza ${ }^{55}$.

Kościelna władza papieska sięgała także do Ilirii Wschodniej, z siedzibą w Tessalonice ${ }^{56}$. Grzegorz pisał w różnych sprawach do biskupów m.in. Koryntu i Krety. Relacje te mącił tu jednak wpływ cesarski. I tu autorytet Grzegorza wystawiony był na próbę, jak np. w przypadku cesarskiej decyzji o przyjęciu w Ilirii biskupów pozbawionych siedzib przez Awarów ${ }^{57}$. J. Czuj napisze wprost, iż biskupi iliryjscy przyzwyczajeni byli swoje sprawy wytaczać przed cesarzem, a nie przed biskupem Rzymu ${ }^{58}$. Podobnie miały się sprawy $z$ biskupami w Afryce, z którymi Grzegorz pozostawał w kontakcie, ale którzy potrafli go ignorować i zwracać się do cesarza. Sytuację komplikuje tu też administracja, bowiem Afryka tworzyła oddzielny egzarchat ${ }^{59}$. I choć miał on tam pewne sukcesy, jak choćby $\mathrm{w}$ walce $\mathrm{z}$ donatyzmem, do której sam inspirowal ${ }^{60}$, to jednak nie można tam mówić o jakimś wielkim autorytecie. Jak zaznaczy to wspominany znawca św. Grzegorza, ,w tamtejszym episkopacie żyło poczucie autonomii. Mógł Grzegorz przypominać, że Kościół afrykański zawdzięcza swe początki Rzymowi, ale tam się tym nie przejmowano. Nie starano się o udzielenie papieżowi dokładnych wiadomości i omijano go, udając się do cesarza. Władze świeckie podtrzymywały lub popierały taką postawę i stanowisko"61. Autorytet biskupa Rzymu sięgał także Korsyki i Sardynii, które choć należały do egzarchatu Afryki, to jednak podlegały również metropolii rzymskiej, z którą więź, choć wcześniej luźna, była przez Grzegorza zacieśniana przez konieczne reformy życia kościelnego ${ }^{62}$.

Jeśli z kolei chodzi o Galię, to w niej także nie można mówić o jakimś wielkim autorytecie biskupa Rzymu. Cieszył się on tam pewnym szacunkiem, próbował wpływać na tamtejszy Kościół, choć bywało, że ten kierował się, podobnie jak na Wschodzie, swoim prawem i zdarzało się, że szukał niekiedy

innego mym zdaniem nie pozostaje, jak tylko po dokładnym śledztwie pozbawić go i tego urzędu, który piastuje". 179, 234.

${ }_{55}$ Por. Epistulae IV 20, 38; V 6, 29, 39; VI 3, 25, 26, 48; VII 17; VIII 11; IX 150, 155, 156, 177 .

56 Por. Czuj, Papież Grzegorz Wielki, s. 105: „Graniczące z Dalmacją Illyricum wschodnie, przynależące politycznie do cesarstwa wschodniego, zorganizowane jako papieski wikariat z siedzibą w Tessalonice, zostało w czasach pochalcedońskich przylączone do patriarchatu Zachodu i podlegalo mu podobnie, jak zachodnie prowincje metropolitalne".

57 Por. Epistula I 43, CCL 140, 57.

58 Por. Czuj, Papiez Grzegorz Wielki, s. 109.

59 Siedzibą egzarchatu Afryki była Kartagina.

${ }^{60} \mathrm{Te}$ kwestię obrazuje kilkanaście listów $\mathrm{z}$ lat $591-598$, które zostały razem wydane, m.in. w: Maier, Le dossier du donatisme, s. 347-381.

${ }_{61}$ Czuj, Papiez Grzegorz Wielki, s. 118; por. Markus, Grzegorz Wielki, s. 229-237.

62 Por. Czuj, Papiez Grzegorz Wielki, s. 119-124. 
rozwiązań nie u rzymskiego biskupa, lecz u swoich władców. Spotykamy tu choćby $\mathrm{i}$ takie kuriozalne przypadki, jak ucieczka przed karą na teren Galii biskupa Teodora ${ }^{63}$ czy ustanowienie - decyzją władzy świeckiej - nowego biskupstwa w części diecezji biskupa Turynu ${ }^{64}$. Należy mieć na uwadze także i to, iż do końca sprawa ta nie została rozwiązana według woli rzymskiego biskupa. Przywołać tu jeszcze warto sprawę symonii i święceń za wynagrodzeniem, które to praktyki próbował Grzegorz usilnie zwalczać, apelując także (bez powodzenia) o zwolanie w tej sprawie synodu ${ }^{65}$. Reasumując trzeba powiedzieć, iż Galia to oddzielny świat, rządzący się częściowo swoimi prawami, świat podzielony na kilka królestw, które dopiero za pewien czas dadzą podstawę pod jednolity organizm, jakim będzie imperium Karola Wielkiego. Jeśli uwzględnimy tę rzeczywistość, to i tak muszą cieszyć takie fakty, jak wpływ Rzymu na życie Kościoła galijskiego, najpierw ograniczony, potem, po wyprawie Augustyna [z Canterbury] do Anglii, stopniowo rozszerzany ${ }^{66}$.

Mniej problematycznie miały się sprawy w Hiszpanii ${ }^{67}$, gdzie spotykamy m.in. przyjaciela Grzegorza, Leandra z Sewilli, któremu zresztą zadedykował swoje Moralia $^{68}$. Pontyfikat naszego papieża przypada na czasy tuż po nawróceniu na katolicyzm Rekkareda, władcy dotychczas ariańskiego kraju ${ }^{69}$. Pisząc doń w sierpniu $599 \mathrm{r}$. był pełen entuzjazmu:

„Nie mogę, Najznakomitszy Synu, wyrazić słowami, jak wielce cieszę się z twego dzieła i z twego życia. Oto na wiadomość o nowym cudzie, który nastąpil za dni naszych, mianowicie, że dzięki Waszej Dostojności cały naród Gotów przeniesiony został z błędu ariańskiej herezji na grunt prawdziwej wiary, miło jest wykrzyknąć z Prorokiem: «Ta jest odmiana prawicy Najwyższego» (Ps 76, 11)»70.

${ }^{63}$ Por. Epistula IX 224, CCL 140A, 797-798.

${ }^{64}$ Por. Epistulae IX 215 i 227, CCL 140A, 775-776 i 801-802.

65 Por. Epistulae V 60; XI 42, 47, 49, 50; J. Leclercq, „Simoniaca haeresis”, w: Studi gregoriani, I, Roma 1947, 523-530.

${ }^{66}$ Por. M.B. Bouvet, Les relations entre les Églises des Gaules et le Siège apostolique (440-604). Études de la correspondance et de sa réception jusqu'à Gratien, w: École nationale des Chartes. Positions des thèses, Chartres 1985, 23-29; Czuj, Papież Grzegorz Wielki, s. 124-134; E. Delaruelle, L'Église romaine et ses relations avec l'Église franque jusqu'en 800, w: Le Chiese nei Regni dell'Europa occidentale e i loro rapporti con Roma sino all'800, Spoleto 1960, 156-161; Markus, Grzegorz Wielki, s. 200-212.

${ }^{67}$ Por. J. Orlandis, Gregorio Magno y España Visigodo-Bizantina, w: Hispania y Zaragoza en la Antigüedad Tardía, Zaragoza 1984, 87-103.

68 Na temat relacji z Leandrem, w latach 579-600 biskupem Hispali (Sewilla), por. D. Ramos Lissón, Grégoire le Grand, Léandre et Reccarède, w: Gregorio Magno e il suo tempo, Studia Ephemeridis „Augustinianum” 33, I, Roma 1991, 188-192. Zachowało się kilka ledwie listów do hiszpańskiego biskupa: Epistulae I 41; V 53; IX 228 oraz list dedykacyjny do Moraliów, zob. San Gregorio Magno, Commento morale a Giobbe, t. 1, Roma 1992, 80-91. List ów figuruje w edycji Czuja pod nr V 53a (Czuj II 138-145).

${ }^{69}$ Miało to miejsce w 587 roku.

70 Epistula IX 229, CCL 140A, 805-806, Czuj III 272. Droga do owego „cudu” byla dosyć żmudna, bowiem Rekkared przeżyl po drodze próbę przewrotu pod wodzą biskupa ariańskiego 
Mimo jednak nawrócenia „całego narodu” nie znajdujemy zbyt wielu świadectw i relacji biskupa Rzymu o tym wydarzeniu. Sam Grzegorz nie wykazywał zbytniej chęci do ingerencji w życie Kościoła hiszpańskiego, być może $z$ powodu odległości, aczkolwiek i tu cieszył się pewnym autorytetem, co widać po fakcie odwoływania się do biskupa Rzymu ze strony niektórych hiszpańskich biskupów $\mathrm{z}$ prowincji Baetica ${ }^{71}$.

Osobny rozdział w działalności Grzegorza stanowi wysłanie czterdziestu mnichów pod wodzą Augustyna do Anglii i zorganizowanie tam kościelnej hierarchii pod kierunkiem wspomnianego duchownego, wpierw opata, a potem biskupa i metropolity w Canterbury ${ }^{72}$. Gdy ci misjonarze, po wielu trudnościach dotarli w końcu do Kentu, przy pomocy króla Ethelberta i jego małżonki Berty zdołali rozbudować organizację kościelną, pozostającą pod silnym wpływem autorytetu biskupa rzymskiego. Wpływ ten, jak już wyżej zaznaczono, umocnił się także, przy okazji misji angielskiej, na terenach kościoła frankońskiego ${ }^{73}$. W ocenie jednak autorytetu rzymskiego biskupa należy mieć się tu na baczności. Mamy bowiem do czynienia, co prawda, z położeniem podwalin pod organizację kościelną, ale daleko jeszcze do ideału. $Z$ jednej bowiem strony mamy do czynienia ze świeżo nawróconym królem, $z$ drugiej zaś zakres oddziaływania misji Augustyna ogranicza się tylko do pewnej części wyspy ${ }^{74}$. W każdym razie przyczólek został uchwycony i choć P. Brown podkreśla kruchość nowej struktury, to K. Schatz całkiem słusznie akcentuje symbolikę posłania przez niego w 601 r. pallium zarówno do Canterbury, jak i do Yorku ${ }^{75}$.

\section{PROBLEM AUTORYTETU BISKUPA RZYMU W RELACJACH Z WŁADZA SWIECKA}

Wszystko to, o czym wspominaliśmy wyżej, nie pozostawało neutralne wobec władzy świeckiej. Po części dotknęliśmy już tej kwestii. Czy biskup

Sunny, spisek pod przewodnictwem królowej - matki, Galswinty i bunt w Septymanii, a samo nawracanie zaowocowalo $\mathrm{m}$. in. tym, iż na tamtych terenach nie zachowaly się w ogóle literackie dzieła ariańskie, por. J. Strzelczyk, Goci-rzeczywistość i legenda, Warszawa 1984, 221-222.

${ }^{71}$ Chodzi o biskupa Malagi Januariusza i biskupa Stefana (brak bliższych danych o tej osobie), zlożonych z urzędu. Rzymski biskup nakazuje zajęcie się tą sprawą, aczkolwiek nie znamy jej zakończenia, por. Epistula XIII 46, 48, 49.

72 Por. D.H. Farmer, St. Gregory the Great and St. Augustine of Canterbury, w: Benedict's Disciples, Leominster 1980, 41-51; A. Furioli, San Gregorio Magno e l'evangelizzazione degli Anglosassoni. Ambiente, storia e metodologia di un'azione missionaria, „Euntes docete" 42 (1989) 471-493.

${ }^{73}$ Por. Markus, Grzegorz Wielki, s. 211-222.

74 Por. Brown, Narodziny zachodniego chrześcijaństwa, s. 242-244.

75 Por. K. Schatz, Prymat papieski od poczatków do wspótczesnosci, tlum. E. Marszal J. Zakrzewski Kraków 2004, 106. 
Rzymu, w tym wypadku św. Grzegorz Wielki, cieszył się wobec niej autorytetem? Od razu można powiedzieć, iż nie sposób odpowiedzieć na to pytanie jednym tylko zdaniem, a rzecz trzeba rozpatrywać z co najmniej kilku punktów widzenia, zależnie od pozycji osoby, z którą miał nasz Swięty do czynienia.

W pierwszym rzędzie należy zapytać o relacje z przedstawicielami Konstantynopola $^{76}$, a tu wymienić zwierzchnią władzę imperium, czyli Maurycjusza, a później Fokasa ${ }^{77}$. Jeśli tu chcielibyśmy doszukiwać się doniosłego autorytetu biskupa Rzymu, to byłoby to niezmiernie trudne: możemy to najwyżej mówić o autorytecie honorowym. Wystarczy tu wspomnieć list Maurycjusza, skierowany do Grzegorza przy okazji prób rozwiązywania problemu Sewera z Akwilei, gdzie cesarz wyraźnie używa sformułowania: „rozkazujemy Twojej Świątobliwości"78. W liście tym to władca wypowiada się w imię Jezusa Chrystusa, choć tytułuje Grzegorza „najświętszym i błogosławionym ojcem”, również „arcybiskupem Rzymu i patriarchą". Grzegorz zaś, pisząc doń, zwie siebie "niegodnym sługą"79, choć równocześnie wyrażając się przeciw zakazowi wstępowania do klasztorów zołnierzy, upomina delikatnie cesarza, przypominając $\mathrm{mu}$, że to od Chrystusa otrzymal zaszczytne stanowisko i używa znaczącej formy: „na to odpowiada Chrystus przeze mnie" ${ }^{\text {, }}$, choć zgłaszając sprzeciw oświadcza równocześnie, że prawo cesarskie respektuje. Ten schemat powtarza się w całej relacji pomiędzy biskupem a władcą ${ }^{81}$.

Nie możemy w tym wszystkim zapominać, że Grzegorz to dyplomata, doskonale znający stosunki wschodnie. W świetle tego, co już wcześniej powiedzieliśmy, możemy pokusić się o twierdzenie, iż zdaje on sobie doskonale sprawę ze swojego autorytetu następcy Piotra, potrafi jednak respektować autorytet strony świeckiej. Uwzględnić tu także należy fakt, iż od czasów Justyniana Kościół i państwo były związane ze sobą bardzo silnie, co także nadaje swoisty styl wzajemnych relacji ${ }^{82}$. W swej dyplomacji nasz rzymski biskup bywa jednak niekiedy przesadny, jak to widzimy w przesłodzonym, skierowanym z okazji objęcia rządów, liście do uzurpatora Fokasa, mordercy rodziny cesarskiej ${ }^{83}$, czy do jego małżonki ${ }^{84}$. Trudno takie postępowanie jasno określić. Dyplomacja, strach, czy gra polityczna? W każdym razie w zakresie

${ }^{76}$ Dobre opracowanie zagadnienia relacji z dworem konstantynopolitańskim znajdujemy w: T. Wolińska, Stosunki papieza Grzegorza Wielkiego z dworem cesarskim i administracją bizantyńskq, Piotrków Trybunalski 1998.

77 Objął tron w wyniku zamachu stanu w r. 602 i zamordowania zarówno Maurycjusza, jak i całej jego rodziny.

78 Epistula I 16b (Czuj), Czuj I 241.

79 Por. Epistula III 61, CCL 140, 209, Czuj I 241.

80 Tamże, Czuj I 242.

${ }^{81}$ Posiadamy kilka listów do Maurycjusza (III 61; V 30, 36, 37; VI 16, 64; VII 6, 30).

82 Por. Markus, Grzegorz Wielki., s. 104-106.

83 Por. Epistula XIII 32, CCL 140A, 1033-1034, Czuj IV 199-200 (34).

84 Por. Epistula XIII 40, CCL 140A, 1043-1044, Czuj IV 208-109 (42). 
poczucia autorytetu biskupa Rzymu tenże Fokas będzie miał swoją zasługę, mianowicie określenie Stolicy Piotrowej „głową wszystkich Kościołów”85.

Swiadomość autorytetu biskupa Rzymu towarzyszyła naszemu Autorowi w relacji choćby do egzarchy, którego po ojcowsku tytułuje „synem”86. Na terenie rzymskim mial biskup Grzegorz także swoisty autorytet władzy wobec wojska, co obrazuje nam korespondencja $\mathrm{z}$ dowódcami w czasie najazdu longobardzkiego w 592 roku ${ }^{87}$.

Jeśli z kolei zapytamy o kwestię autorytetu Grzegorza u władców barbarzyńskich, to z pewnością nie jest on wielce respektowany przez Longobardów, choć nie można mówić o jego braku, skoro prowadził z nimi układy pokojo$w^{88}$. Autorytet Piotra musial też mieć znaczenie u królowej Teodelindy, skoro w korespondencji tytułował ją „najznakomitszą córką"89. Nie dziwi to zresztą, skoro była ona katoliczką.

Autorytet św. Piotra stawiał Grzegorz także w relacjach z królową Brunhildą z Galii. Jak określi to J. Czuj, Grzegorz „uważał księcia Apostołów za magnes o bardzo wielkiej sile przyciągania" 90 .

W stosunku do królów nie zachowywał nasz rzymski biskup takiego respektu, jak wobec imperatora. Tytulował zarówno Teoderyka II, Teudeberta II, jak i Klotara zaledwie „ekscelencją"91. Mało tego, Frankowie u niego właśnie próbowali szukać pośrednictwa między sobą a cesarzem. $Z$ tej idei jednak nic nie wyszło, ale warte jest to odnotowania, bo także mówi o autorytecie tego biskupa ${ }^{92}$. O wyjaśnienie kwestii relacji z Bizancjum prosił także Rekkared, król wizygockiej Hiszpanii, darzący respektem Grzegorza ${ }^{93}$. Również i dla Etelberta, króla Kentu, i jego małżonki Berty, Grzegorz, który tytułował króla „synem"94, ma duże znaczenie. Ze swej strony i on nawoływał świeżo nawróconego króla do pogłębiania chrześcijańskiej wiary ${ }^{95}$.

${ }^{85}$ Chodzi o pismo skierowane do Bonifacego III w 607 r., por. A. Krawczuk, Poczet cesarzy bizantyjskich, Warszawa 1992, 205.

${ }^{86}$ Por. Epistula XIII 34, CCL 140A, 1035-1037, Czuj IV 201-103 (36).

87 Por. Epistulae II 4, 27, 28.

${ }^{88}$ Por. Epistulae IV 2; V 34, 36; IX 11, 44, 66, 196; X 16; XIV 12.

89 Por. Epistula IX 67.

90 Czuj, Papież Grzegorz Wielki, s. 127.

91 Por. Epistulae XI 47, 50, 51.

92 Por. Epistulae XIII 5 i 7.

93 Por. Epistula IX 229. O relacjach z Rekkaredem zob. szerzej w: Ramos- Lissón, Grégoire le Grand, Léandre et Reccarède, s. 193-196.

${ }^{94}$ Por. Epistula XI 37.

${ }^{95}$ Por, tamże. 
Nie sposób ogarnąć całości podjętego problemu na kilku zaledwie stronach ogólnego opracowania. Nie zapuściliśmy się zbyt głęboko w obszar autorytetu duchowego i moralnego św. Grzegorza. To samo można powiedzieć także i o autorytecie prawniczym. Te aspekty warto jeszcze dopracować w oddzielnej publikacji. Należą one jednak chyba bardziej do sfery autorytetu tej konkretnej osoby, a nie biskupa Rzymu w ogólności, choć niewątpliwie płaszczyzny te wzajemnie się przenikają.

Podsumowując nasze rozważania można raz jeszcze podkreślić, że dla św. Grzegorza autorytet biskupa Rzymu leżał w sukcesji płynącej od św. Piotra i w reprezentowaniu Chrystusa. $Z$ tym duchowym znaczeniem okazuje się też łączyć może jeszcze nie autorytet, ale zalążek autorytetu władzy papieskiej, który rozkwitnie już niebawem. Na razie biskup Rzymu, choć pierwszy pośród patriarchów, dysponuje niewątpliwym, ale nie aż tak wielkim znaczeniem, bo musi respektować imperatora $z$ jednej strony, a i liczyć się z barbarzyńcami, czy opornymi biskupami, także zachodnimi, z drugiej. Nie można jednak zapomnieć, że ci barbarzyńcy są już w większości chrześcijanami, jak Teodelinda, Berta, Etelbert, Brunhilda, czy Rekkared, zaś ci biskupi - lub ich następcy zrozumieją jednak autorytet rzymskiego papieża. Rodzi się nowy świat, a w kładzeniu podwalin św. Grzegorz Wielki, biskup Rzymu, ma swój niewątpliwy udział, poświadczony tytułem nadanym mu przez potomność.

\title{
L'AUTORITE D'EVEQUE DE ROME DANS L'ENSEIGNEMENT ET LA PRACTIQUE DE SAN GRÉGOIRE LE GRAND
}

\author{
(Résumé)
}

En demandant de rôle d'évêque de Rome dans l'antiquité il serait bien se referer à l'œuvre d'auteur qui lui même exerçait cette mission et, en plus, il nous a lessait un témoignage suffisamment fort. Saint Grègoire le Grand (540-604) accomplit tres bien cette tache. Il forme un solide point culminante d'epoque patristique, en même temps il est un intermédiaire specifique entre l'antiquité chretienne et Moyen Âge.

L'autorité d'évêque de Rome, selon notre auteur résulte de commandement de même Christ et de le rôle de saint Pierre, le premier évêque de la „Ville Eternelle”. Cette autorité, généralement pas contesté, il a été perçu de différentes maniéres, selon la region geografique, les traditions particulieres, finallement aussi selon la fonction et même le caractère des personnages, avec les quelles saint Grégoire a tenu des relations. 
Si nous regardions a l'Est, nous rencontrons d'estime en face de l'évêque romaine, mais aussi des tentatives individualistes, specialement de la part de l'évêque constantinopolitain. Il ne manque pas des problems dans l'Occident, où à la vérité ce ne met pas en doute l'autorité de l'évêque de Rome, mais aussi il ne manque pas des questions disciplinaires jointes à sumission a cette autorité. La même chose concerne les relations avec des souverains, ceux de Constantinople et ceux des royaumes barbares.

Dans la lumiere de la literature analisée, nous decouvrons une verité partiellement belle, parce que elle nous informe de l'estime envers l'évêque de Rome, partiellement triste, parce que nous rencontrons des questions dificiles. C'est la verité de temps de la naissance d'un monde nouveau, le Moyen Âge. Saint Grègoire le Grand est un temoin éminent de ce procesus. 